\title{
SCHOOLS CLOSURES DURING THE COVID-19 PANDEMIC: A CATASTROPHIC GLOBAL SITUATION
}

Danilo Buonsenso ${ }^{1,2,3, *}$, Damian Roland ${ }^{4,5, *}$, Cristina De Rose ${ }^{1}$, Pablo Vásquez-Hoyos ${ }^{6,7,8}$, Bazlin Ramly ${ }^{9}$, Jessica Nandipa Chakakala-Chaziya ${ }^{10}$, Alasdair Munro ${ }^{11,12}$, Sebastián GonzálezDambrauskas $^{13,14}$

${ }^{1}$ Department of Woman and Child Health and Public Health, Fondazione Policlinico Universitario A. Gemelli IRCCS, Rome, Italy

${ }^{2}$ Dipartimento di Scienze Biotecnologiche di Base, Cliniche Intensivologiche e Perioperatorie,

Università Cattolica del Sacro Cuore, Rome, Italy;

${ }^{3}$ Center for Global Health Research and Studies, Università Cattolica del Sacro Cuore, Roma, Italia

${ }^{4}$ SAPPHIRE Group, Health Sciences, Leicester University, Leicester, UK

${ }^{5}$ Paediatric Emergency Medicine Leicester Academic (PEMLA) Group, Children's Emergency Department, Leicester Royal Infirmary, Leicester, UK

${ }^{6}$ Universidad Nacional de Colobmia, Bogota, Colombia.

${ }^{7}$ Fundacion Universitaria de Ciencias de la Salud, Bogota, Colombia

${ }^{8}$ Sociedad de Cirugia Hospital de San Jose, Bogota, Colombia.

${ }^{9}$ Raji Permasuri Bainun Hospital, Ipoh, Perak, Malaysia

${ }^{10}$ Pediatric Department, Muzu Central Hospital, Ministry of Health, Malawi 
${ }^{11}$ NIHR Southampton Clinical Research Facility and NIHR Southampton Biomedical Research Unit, University Hospital Southampton NHS Foundation Trust.

${ }^{12}$ Faculty of Medicine and Institute for Life Sciences, University of Southampton, Southampton, UK.

${ }^{13}$ Cuidados Intensivos Pediátricos Especializados (CIPe), Casa de Galicia, Montevideo, Uruguay

${ }^{14}$ Red Colaborativa Pediátrica de Latinoamérica (LARed Network), Montevideo, Uruguay

* Both first authors

\section{Corresponding author:}

Danilo Buonsenso

danilobuonsenso@gmail.com

Largo A. Gemelli 8, 00168, Rome, Italy

+390630154390

Twitter: @surf4children

Conflict of Interests: nothing to declare

Funding: nothing to declare 


\begin{abstract}
School closures (SC) were adopted globally as a COVID-19 disease pandemic containment strategy. This extreme measure provoked a disruption of the educational system involving hundreds of million children worldwide. The return of children to school has been variable and is still an unresolved and contentious issue. Importantly the process has not been directly correlated to the severity of the pandemic's impact and has fueled the widening of disparities, disproportionately affecting the most vulnerable populations. Available evidence shows SC added little benefit to COVID-19 control whereas the harms related to SC severely affected children and adolescents. This unresolved issue has put children and young people at high risk of social, economic and healthrelated harm for years to come, triggering severe consequences during their lifespan. In this article we describe the process of SC and the reopening timetable across the globe. We highlight the data regarding the international state of educational systems around the world, putting emphasis on the rights of children to come back to school.
\end{abstract}

Kaywords: COVID-19, children, students, school closures, global situation 
"Education is the most powerful weapon which you can use to change the world."

Nelson Mandela

\section{INTRODUCTION}

In early 2020, school closures (SC) were one of the first non-pharmaceutical interventions adopted almost simultaneously around the world as a COVID-19 disease containment strategy. With the exception of east Asia which commenced SC during January-February, by end of march SC affected the normal academic routine of 1.5 billion learners (84\% worldwide total) across 169 countries of the world (1). This drastic and unparalleled educational disruption was motivated by the uncertainty of the risks the SARS-COV2 virus posed to children and also by the assumption that children could be important vectors for the spread of the new disease. The rationale behind the usefulness of SC as a pandemic control measure could be found in different modeling studies which suggested to apply this public health measure for influenza virus pandemics (2). The World Health Organization recommended SC as a mitigation strategy for these viruses after the experience with pandemic H1N1 in 2009 (3). These considerations seemed to justify the obvious harms related to $\mathrm{SC}$ in the short to medium term.

However, early on in the pandemic the international community realized than COVID-19 infection represented a significantly lower risk for children than adults, and that children seemed less important vectors for SARS-CoV-2 transmission than for previous respiratory virus pandemics (48). A growing body of evidence subsequently showed that children were not super spreaders, and it became clearer than the harms related to SC outweighed the benefits (9). Unfortunately, the global decision to get back to school did not mirror the rapid decision to close them. Whereas SC was almost a unanimous step, school reopening has become one of the most discussed and contentious issues of the current pandemic and a consistent wave of reopening did not occur. In fact the opposite; despite a general scientific consensus that schools were not COVID-19 hot spots (10), still millions of children are not attending their optimal learning environment. 
In this article we aim to describe the process of school reopening and how it related to COVID-19 disease regional impact across the world. In order to assess SC worldwide during the pandemic, we collected information from two different perspectives. Initially, we interviewed professional contacts from around the world who based on their knowledge, or a simple search for local data, allowed us to describe the situation in different countries (supplementary figures 1 and 2). This version was uploaded on a preprint server and shared on social media gaining an altimetric index of more than 600 within the first 24 hours and receiving several comments and "live revisions". Since some concerns have been raised regarding the methodology used to collect country information, we updated the figures using data from available from the The Oxford COVID-19 Government Response Tracker (OxCGRT), which collects daily information on school closures from more than 180 counties (figure 1 and figure 2). In this dataset school closures is categorized into four groups: 0 - no measures taken, 1 - either governments recommend (not require) on closing or all schools were open but with some alterations; 2 - government require closing at some levels or by categories (age, financial), 3 - government require closing all levels. We analyzed the timelines according to the number of days schools were open (0 or 1), partially open (2), or fully closed (3) based on the collected information (figure 1). We analyzed timelines according to the number of days schools were open, partially open, or fully closed based on the collected information. We also geocoded (figure 1 and figure 2) maps and also created a heat map using online available information of deaths from COVID-19 per month by country (https://ourworldindata.org/covid-cases; accessed 20 nov 2020) (11) to contrast with the opening of schools.

\section{SCHOOL CLOSURES AND REOPENINGS ACROSS THE WORLD DURING 2020}

With few exceptions (such as Nicaragua, Sweden or Taiwan which never closed schools), SC were widely implemented across the globe during 2020. According to UNESCO monitoring, as of November $23^{\text {rd }}$, there were still over 220 million learners affected by SC, with 23 country-wide closures due to COVID-19 (1). 
Strikingly, as shown in Figure 1, schools reopening was variable across countries and the process was not directly correlated to the severity of pandemic impact (measured by COVID-19 deaths). Africa and Europe demonstrate two sides of this spectrum. Although Africa has had an overall relative low death toll most countries currently still have SC enacted. According to the UNICEF, only 7 (Benin, Burkina Faso, Cabo Verde, Chad, the Republic of the Congo, Equatorial Guinea, and Sierra Leone) out of 24 countries in the Central and West African region have reopened their schools after COVID-19 mandatory lockdowns and managed to prepare their schools and put measures in place to ensure that students can safely return (12).

Conversely, most of Western Europe prioritized the reopening of schools despite having a significant second wave of COVID-19 during the autumn which has leading to broad social restrictions again (13). In early November, UK guidance for school reopening stated that "it continues to be the aim that all pupils, in all year groups, remain in school full-time throughout the autumn term" and that "returning to school is vital for children`s education and for their wellbeing" (14). Current data from European countries with similar decisions is consistent with schools, especially for younger children, not playing a defining role in amplifying community transmission. For example the reopening of schools played a subordinate role in the spread of SARS-CoV2 during the second wave in Germany $(15,16)$. Similarly Northern countries like Finland and Denmark, that reopened schools in the spring, after the first wave, did not report particular increases in cases of contagion (17). In particular, Denmark was the first Western country to reopen kindergartens and elementary schools and subsequently recorded a steady decrease in cases nationwide (18).

Despite the available empirical evidence $(6,16,19)$ finding that SC have modest impact on community transmission, and that that the resumption of lessons does not seem to have had a negative influence on the growth of the epidemic even in hot-spot regions, schools reopening 
decision is heterogeneous in Europe. Governments are acting with different strategies, some more prone to keep all schools open (Northern and Western Europe), while others are more hesitant like Southern and Eastern Europe. For example, in Italy the closure of secondary schools was envisaged (with consequent distance learning) in the so-called "red areas" where the lock down was established starting from 3 November (20). Although data supports a low transmission of SARSCoV-2 within Italian schools (specially for younger students), entire schools are frequently closed in the fear of larger outbreaks (19). The Czech Republic and countries from the Balkans after reaching one of the highest levels of contagion in the world, have decided to close all schools, except kindergartens, with the prospect of reopening once a significant decline of cases is reached $(21,22)$.

So far, the only published experience highlighting concerns with the safety of school reopening was in Israel. After enacting SC early in March and experiencing a limited first wave of infections, Israel reopened schools in May alongside most other sectors of society. A series of decisions possibly arising from the practice of Orthodox Judaism (23), has led to numerous outbreaks, forcing Israel to close hundreds of schools and blaming educational centers for the surge in cases and forcing a total lockdown again at the end of September. In October, new analysis from scientists of the University of Jerusalem investigated these outbreaks and stated the educational system was not the reason for the second COVID-19 wave in the country (24), since many other factors including residential Orthodox education, the Arab sector wedding season and families simultaneously returning from summer vacations were all correlated to the timing of reopening. In recent weeks, some restrictions have been removed and, for example, kindergartens have been reopened, with the prospect of reopening the other schools as well.

Our research and the resulting map (Figure 2) demonstrates a profound inequality and lack of homogeneity between countries to the detriment, in particular, of the poorest countries in the world which are not yet able to guarantee the safe reopening of schools. In fact, while in other parts of the 
world schools have been gradually reopened and different strategies are adopted to keep most of them open, in regions such as Latin America and/or Africa the vast majority of schools remain closed with no prospect of reopening in the immediate future.

The current situation in Latin America is dramatic. As of November, there were more than 13 million cases of coronavirus reported (25), almost half of country-wide closures came from this region where the schools of 18 out of 36 countries remain closed and most of countries do not have clear reopening plans for the months to come. A recently released analysis from UNICEF reported that $97 \%$ of students of the region (accounting for 137 million children) remain with their normal education disrupted (26). The report estimates that 3.1 million boys, girls and adolescents will drop off the schools for ever due to COVID-19 crisis.

The country with the highest COVID-19 death toll in the world, the United States, took the first step for reopening during the fall after months of SC with supporting scientific editorials declaring that public schools (where more than $90 \%$ of north American students attend) should be recognized as essential services and CDC guidelines recommending mitigation measures for a safe reopening $(17,27)$. State governments have adopted different positions and reopening across the country has been erratic, with prolonged SC poorly correlated to regional burden of infection. Implementation of distance/virtual learning has been piecemeal, with studies showing children from minority or low socioeconomic backgrounds to be receiving the lowest quality of education (28). The first major city to reopen schools was New York in September. Surprisingly, although viral transmission remained very slow and school chancellors declaring "our schools have opened and have been remarkably safe", policymakers decided to close them again in November with no data supporting the decision after a surge of COVID-19 cases within the city (29). The situation in New York shows drivers for SC and reopening have not always been driven by scientific evidence as the American Academy of Pediatrics policy statement suggests needs to occur (30). 
An important limitation when interpreting the figures 1 and 2 is the arbitrary term "partial" which must be considered since reopening process had huge variation between and within countries. For example, Uruguay, which decided full SC the day after detecting the first national case of COVID19 (April $14^{\text {th }}$ ), was also the first Latin American country which reopened rural primary schools for face-to-face teaching in June $1^{\text {st }}(31)$. Then Urban schools were reopened in a staggered and voluntary approach throughout June in the rest of the country. During the whole process school attendance was not mandatory until October 2020 and the decision-making process involved multiple actors (Presidency of the Republic, Ministry of Education, Ministry of Health and the National Public Education with an advisory scientific honorary group) which made protocols and guideline for resumption of school-based education. The lack of infrastructure to attain the required physical distancing between students for many educational centers and the lack of investment in the development of new infrastructure made the process difficult to fulfill that every child could attend every day and centers decided to shorten the period of schooling, dividing groups of learners through the week. Unfortunately, as of mid-November, there is no central precise data of how many students have effectively returned to classes.

\section{IATROGENIC SOCIAL HARM RELATED TO SCHOOL CLOSURES}

There is substantial evidence demonstrating SC are a higher risk to children than COVID-19. Prolonged SC is a social crisis and a stolen future. Schools play an essential role in the education, health and wellbeing of children and the communities they live in. SC can fuel social, economic, and cultural inequalities with a domino effect which can last for generations.

For example, in World War II, one of the less obvious impacts was the disruption of school learning, which had a negative economic impact lasting at least 40 years according to some estimates (32). Less schooling means less human capital, projected to negatively impact future 
earnings of children. Lower academic achievement would translate into long term economic costs for societies. It is estimated that every year loss of schooling would equate to a $10 \%$ loss of future earnings and the additive effects across society could huge costs (33) Recently, the World Bank estimated that a school shutdown of 5 months could value of $\$ 10$ trillion in terms of learning losses (34). Moreover, the COVID-19 related economic recession could even increase the gap in funding, shorten by millions the projected budgets for education in the years to come and thus put at risk the agreed 2030 sustainable development goal on education in low and middle income countries (35).

Impacts of loss of education on future opportunities can be estimated in life years lost. Studies have attempted to quantify this, (36) although these methodologies remain controversial due to inherent difficulties in assessing causality and accurately estimating model parameters. Nevertheless, it remains an important consideration that lost time in education for a population results in fewer life opportunities, lower standard of living, poorer health, and potentially years of life lost as a result in the longer term.

During the COVID-19 crisis, some experts have warned about the high risk of hysteresis of educational system induced by SC. This theoretical model describes the complex interaction between the intensity of learning with student engagement and the current "off grid" situation for thousands of children, which will have enduring consequences (37). This hysteresis of course, will be much more prevalent among the more disadvantaged students coming.

SC could amplify gender inequalities and reverse equality progression from previous decades. Early in the pandemic, the United Nations warned SC could amplify gender inequalities and reverse equality progression from previous decades, particularly in regard to children's main caregivers (38). Pandemic-related job losses have disproportionally affected women, particularly those from 
disadvantaged groups such as immigrants, young adults and other minorities (39). SC might have bolstered gender gaps in education and female empowerment, particularly those living in the most disadvantaged countries (40). SC can worsen an already severe food security crisis during COVID19 crisis (41). According to the World Food Program from WHO, 80 million students in Latin America are losing healthy food and are now at risk of nutrition deficiencies. This will cost lives.

There are parallel silenced and hidden pandemics during the COVID-19. SC forces children to spend more time within their homes where most child abuse occur. The concomitant disruption in violence prevention and response services during 2020 might hide the real figures, with potential under diagnosis and under reporting of violence against children (42). It should not be a surprise in times of economic recession and severe socio-emotional stress and uncertainty that a wave of violence occurs against children. Besides physical harm, a rise on mental health disease could arise, as SC remain (43). Children and adolescents are an especially vulnerable population as daily routines are disrupted and long-lasting social consequences (like social competence, logical deduction or self-control) are vast (44). Researchers working in mental health were worried about the effects of social isolation on self-harm and suicide early in the pandemic (45). Although there is no available data suggesting a rise of these mental disorders during the pandemic in children (46), child psychologists highlight the rising anxiety, loneliness and the damaging long-term consequences of lack of face-to-face contact of young people with their peers (47).

The prolonged interruption of child education services deprives children of the learning experiences necessary for their full development, especially at this stage of their life when they need it most. Overall, school closures are having a significant negative impact on each student's learning and their ability to develop critical thinking and social skills (36). UNICEF data shows that, in a region characterized by high levels of inequality, COVID-19 has exacerbated this situation in terms of education availability (12). The most disadvantaged children -including those with cognitive and 
physical disabilities, refugees and migrants, and girls in particular- face even greater exclusion from the learning process. In countries where inequalities are more pronounced, boys and girls, without school to attend, are more vulnerable to issues such as early pregnancy, child marriage, and recruitment into local armed groups (35).

Those living in poorer environments (who attend to public schools almost by default) will have greater difficulties if they do not have access to technology required for distance learning, including a computer, the Internet or even a desk as UNICEF recently underlined (48). This will widen the gap between the poor and the richer layers from societies, accelerating inequalities and making the bridging of those gaps much more difficult for future generations. In Latin-American, whereas $3 / 4$ students from private schools could access virtual on-line learning only half of those from public schools were able to (48). Distance learning approaches also do not work for younger children as they require direct interactions through play or other motivational activities (49). Distance learning the proposed substitute as educational mean during the pandemic- is still a chimera for millions.

\section{FUTURE STEPS TOWARDS A BLURRED HORIZON}

Available evidence throughout 2020 clearly shows SC, especially for younger children, had relatively minor contribution to control of disease transmission and created significant and potential long-standing harms for an entire generation of children and adolescents. Although children were relatively spared from COVID-19, they have suffered disproportionally to the pandemic response and have been neglected and subjugated to decisions adults have decided in the policy making process as a result. Compelling evidence show that each day with schools closed adds little benefit for COVID-19 but created fertile ground for irreversible damage to a generation of millions.

Countries that have yet to open their schools are putting children and young people at risk of problems that could seriously interfere with their access to education. Beyond the immediate 
impact, the losses this generation may suffer in education and human potential undermine the hopes of the poorest countries for its economic recovery and long-term development.

Investments in public education need to be protected and incentivized so that schools can be physically ready for opening by providing water, sanitation and hygiene as soon as possible. ${ }^{12,48}$ In this way, in a future prospective, governments can "rebuild better", laying the foundations for education systems to provide not only better learning, but also a safer and more resilient environment than which existed before the pandemic. Many schools even in high income countries are in dilapidated buildings which have proved difficult to provide sufficient ventilation for optimum infection prevention (50). "With every day that goes by, millions of children and young people unable to safely access learning opportunities are missing out on their right to an education and putting their future at risk," regional director Marie-Pierre Poirier said in a statement (48).

In words of United Nations Secretary-General Antonio Guterres "Now we face a generational catastrophe that could waste untold human potential, undermine decades of progress, and exacerbate entrenched inequalities" (35). In November UNICEF proposed a six-point plan to avert a "lost COVID generation" (51). The first one is "to ensure all children learn, including by closing the digital divide". There is no surprise in this prioritization. The longer schools are closed, the worse future they will have during their shortened lifespan. In a year of uncertainty, the evidence shows and children`s rights mandate that we should act urgently to restore school functioning as a top global priority without further delay.

$\mathrm{SC}$ are at the core of the crisis. Schools have always been at the heart of the rights of children and adolescents and their families. Leaving students at home from primary to high school undermines and tramples on the right to education and the rights of families. It contravenes the UN Convention on the rights of the child signed by the States parties "the right of children to education, and with a 
view to achieving this right progressively and on the basis of equal opportunity" (52). Over prolonged periods, schools closures are more damaging to children and to society in the long term than risks of transmission of COVID-19. We cannot let ourselves to treat them worse than the novel virus.

\section{CONCLUSION}

The international approach to the reopening of schools has been chaotic and fragmented, both internationally and even within national borders. There has been a lack of impetus in many countries to recognize the essential nature of educational facilities in the health and wellbeing of children, and a disproportionate focus on their potential role in disease transmission due to the framing of previous influence pandemics. The issues are exacerbating entrenched inequalities within nations, disproportionately harming children and families who are already the most vulnerable. At a global level, schools have been reopened predominantly in wealthy nations in North America and Western Europe whilst they remain closed across swathes of the continents of South America and Africa, lead to deepening health, social and economic divides between high and low/middle income countries. A coordinated global effort is required to urgently return children to in person schooling (with a focus on the youngest children) to prevent further harms to the futures of children and young people, and stem the tide of deepening inequality.

\section{Acknowledgments}

We are thankful to the social media community that, after uploading the preprint of our manuscript, contributed with a productive discussion in improving the analyses and representation of school closures worldwide.

We are grateful to colleagues from all over the world that supported this study providing national data about school closure: Luis Llano, Roberto Jabornisky, Diego Vinciguerra, Nils Cassoon, 
Regina Grigolli, Vanessa Lanziotti, Pietro Pietroboni, Adriana Yock, Valeria Defaz, Alcides Díaz Claros, Rubèn Ruíz Santa Cruz, Millie Figueroa, Jesús Domínguez, Amadu Juliana, Miguel Angel Luzardo Urdaneta, Miguel Rodríguez-Rubio, Francisco Abecasis, Sebastian Baier-Grabner, alix Flamant, Mihael Plosnic, Andreea Madaline Panciu, Pietro Sollena, Johanna Lempainen, Silvia Simò Nebot, Amelie Sandart, Yonca Bulut, Vira Chechenyeava, Arun Bansal, Bahareh Yaghmaie, Hussam Inany, Jackie Ong, Rashan Haniffa, Qalab Abbas, Ryuichi Waseda, Fiona Muttalib, Hussam Inany, Emma Luisa Binns, Chifuniro Kamwendo, Jana Rodríguez-Hertz. 


\section{REFERENCES}

1. UNESCO. Education: From disruption to recovery. Accessed 11/24/2020, https://en.unesco.org/covid19/educationresponse

2. Jackson C, Mangtani P, Hawker J, Olowokure B, Vynnycky E. The effects of school closures on influenza outbreaks and pandemics: systematic review of simulation studies. PLoS One. 2014;9(5):e97297. doi:10.1371/journal.pone.0097297

3. Reducing transmission of pandemic (H1N1) 2009 in school settings. A framework for national and local planning and response: World Health Orgnization; 2009. p. 7.

4. Götzinger F, Santiago-García B, Noguera-Julián A, et al. COVID-19 in children and adolescents in Europe: a multinational, multicentre cohort study. Lancet Child Adolesc Health. 09 2020;4(9):653-661. doi:10.1016/S2352-4642(20)30177-2

5. Viner RM, Mytton OT, Bonell C, et al. Susceptibility to SARS-CoV-2 Infection Among Children and Adolescents Compared With Adults: A Systematic Review and Meta-analysis. JAMA Pediatr. Sep 2020;doi:10.1001/jamapediatrics.2020.4573

6. Macartney K, Quinn HE, Pillsbury AJ, et al. Transmission of SARS-CoV-2 in Australian educational settings: a prospective cohort study. Lancet Child Adolesc Health. 11 2020;4(11):807816. doi:10.1016/S2352-4642(20)30251-0

7. Kim J, Choe YJ, Lee J, et al. Role of children in household transmission of COVID-19. Arch Dis Child. Aug 2020;doi:10.1136/archdischild-2020-319910

8. Goldstein E, Lipsitch M, Cevik M. On the effect of age on the transmission of SARS-CoV-2 in households, schools and the community. J Infect Dis. Oct 2020;doi:10.1093/infdis/jiaa691

9. Munro APS, Faust SN. Children are not COVID-19 super spreaders: time to go back to school. Arch Dis Child. 07 2020;105(7):618-619. doi:10.1136/archdischild-2020-319474

10. Lewis D. Why Schools Probably aren't Covid Hotspots. Nature. 2020;587(7832)doi:10.1038/d41586-020-02973-3 
11. Ritchie H, Ortiz-Ospina E, Beltekian D, et al. Coronavirus (COVID-19) Cases - Statistics and Research. OurWorldInData.org. Accessed 11/20/2020, https://ourworldindata.org/covid-cases

12. Only 1 in 3 countries have re-opened school in West and Central Africa. 2020. https://www.unicef.org/wca/press-releases/only-1-3-countries-have-re-opened-school-west-and-

\section{central-africa}

13. Kmietowicz Z. Covid-19: "There is no alternative," says Johnson, announcing new restrictions for England. BMJ. Nov 2020;371:m4247. doi:10.1136/bmj.m4247

14. Guidance for full opening: schools. GOV.UK. Accessed 11/11/2020, https://www.gov.uk/government/publications/actions-for-schools-during-the-coronavirusoutbreak/guidance-for-full-opening-schools

15. von Bismarck-Osten C, Kirill Borusyak K, Schönberg U. The Role of Schools in Transmission of the SARS-CoV-2 Virus: Quasi-Experimental Evidence from Germany. Discussion Paper Series. Centre for Research and Analysis of Migration; 2020. Nov 20. https://www.creammigration.org/publ_uploads/CDP_22_20.pdf

16. Isphording IE, Lipfert M, Pestel N. School Re-Openings after Summer Breaks in Germany Did Not Increase SARS-CoV-2 Cases. Discussion Paper Series. dp13790. IZA Institute of Labor Economics; 2020. Oct. http://ftp.iza.org/dp13790.pdf

17. Levinson M, Cevik M, Lipsitch M. Reopening Primary Schools during the Pandemic. N Engl J Med. 09 2020;383(10):981-985. doi:10.1056/NEJMms2024920

18. Ritchie H, Ortiz-Ospina E, Beltekian D, et al. Denmark: Coronavirus Pandemic Country Profile. Accessed $11 / 16 / 2020$ https://ourworldindata.org/coronavirus/country/denmark? country= DNK

19. Buonsenso D, De Rose C, Moroni R, Valentini P. SARS-CoV-2 infections in Italian schools: preliminary findings after one month of school opening during the second wave of the pandemic. medRxiv. 2020:2020.10.10.20210328. doi:10.1101/2020.10.10.20210328 
20. [On purpose: Decree of the president of the council of ministers, 3 November 2020, further implementation provisions form the "Urgent measures to deal with the epidemiological emergency from COVID-19”] (Ministero dell'Istruzione.) (2020).

21. Czech government enacts new measures to curb coronavirus. Politico; 2020. https://www.politico.eu/article/czech-government-enacts-new-measures-to-curb-coronavirus/

22. Vladisavljevic A, Todorov S, Marusic SJ, Dragojlo S, Bami X, Kajosevic S. Southeast Europe's Schools Face COVID-19 Challenge as Pupils Return Balkan Insight. September 17, 2020. https://balkaninsight.com/2020/09/17/southeast-europes-schools-face-covid-19-challenge-aspupils-return/

23. Schattner A, Klepfish A. Orthodox Judaism as a Risk Factor of Covid-19 in Israel. Am J Med Sci. 09 2020;360(3):304. doi:10.1016/j.amjms.2020.05.037

24. Jaffe-Hoffman, Maayan. 'School system not responsible for latest coronavirus outbreak'. The Jerusalem Post. https://www.jpost.com/israel-news/school-system-not-responsible-forcoronavirus-second-wave-644058

25. Dong E, Du H, Gardner L. An interactive web-based dashboard to track COVID-19 in real time. Lancet Infect Dis. 05 2020;20(5):533-534. doi:10.1016/S1473-3099(20)30120-1

26. COVID-19: over 97 per cent of students still out of the classrooms in Latin America and the Caribbean. 2020. https://www.unicef.org/press-releases/covid-19-over-97-cent-students-still-out$\underline{\text { classrooms-latin-america-and-caribbean }}$

27. CDC. Operating schools during COVID-19: CDC's Considerations. Center for Disease Control and Prevention. Accessed 11/26/2020, https://www.cdc.gov/coronavirus/2019ncov/community/schools-childcare/schools.html

28. Diliberti M, Kaufman JH. This School Year Be Another Casualty of the Pandemic? Key Findings from the American Educator Panels Fall 2020 COVID-19 Surveys. The RAND Corporation. Accessed 11/30/2020, https://www.rand.org/pubs/research_reports/RRA168-4.html 
29. Shapiro E. New York City to Close Public Schools Again as Virus Cases Rise. The New York times. https://www.nytimes.com/2020/11/18/nyregion/nyc-schools-covid.html

30. AAP. COVID-19 planning considerations: guidance for school re-entry. American Academy of Pediatrics. Accessed 10/19/2020, https://services.aap.org/en/pages/2019-novel-coronaviruscovid-19-infections/clinical-guidance/covid-19-planning-considerations-return-to-in-personeducation-in-schools/

31. UNICEF. Early opening of schools in Uruguay during the COVID-19 pandemic. Accessed 11/28/2020, https://www.unicef.org/uruguay/en/reports/early-opening-schools-uruguay-during$\underline{\text { covid-19-pandemic }}$

32. Ichino A, Winter-Ebmer R. The Long-Run Educational Cost of World War II. Journal of Labor Economics. 1998;22(1):57-85. 07/01. https://www.journals.uchicago.edu/doi/abs/10.1086/380403

33. Psacharopoulos G, Patrinos H, Collis V, Vegas E. The COVID-19 cost of school closures. 11/24/2020, 2020. https://www.brookings.edu/blog/education-plus-development/2020/04/29/the$\underline{\text { covid-19-cost-of-school-closures/ }}$

34. Azevedo JP, Hasan A, Goldemberg D, Iqbal SA, Geven K. Simulating the Potential Impacts of COVID-19 School Closures on Schooling and Learning Outcomes : A Set of Global Estimates. World Bank; 2020. https://openknowledge.worldbank.org/handle/10986/33945

35. UNESCO. how many students are at risk of not returning to school? Accessed 10/6/2020, https://unesdoc.unesco.org/ark:/48223/pf0000373992

36. Christakis DA, Van Cleve W, Zimmerman FJ. Estimation of US Children's Educational Attainment and Years of Life Lost Associated With Primary School Closures During the Coronavirus Disease 2019 Pandemic. JAMA Netw Open. 11 2020;3(11):e2028786. doi:10.1001/jamanetworkopen.2020.28786 
37. OECD. Focusing on the long-term impact of school closures. Organisation for Economic Co-operation and Development. Accessed 11/26/2020, https://www.oecd.org/coronavirus/policyresponses/education-and-covid-19-focusing-on-the-long-term-impact-of-school-closures-2cea926e/

38. UN. The Impact of COVID-19 on Women. United Nations. Accessed 11/26/2020, https://www.unwomen.org/-

/media/headquarters/attachments/sections/library/publications/2020/policy-brief-the-impact-of$\underline{\text { covid-19-on-women-en.pdf }}$

39. Kochhar, Rakesh. Hispanic women, immigrants, young adults, those with less education hit hardest by COVID-19 job losses. Pew Research Center. https://www.pewresearch.org/fact$\underline{\text { tank/2020/06/09/hispanic-women-immigrants-young-adults-those-with-less-education-hit-hardest- }}$

\section{by-covid-19-job-losses/}

40. Burzynska K, Contreras G. Gendered effects of school closures during the COVID-19 pandemic. Lancet. 06 2020;395(10242):1968. doi:10.1016/S0140-6736(20)31377-5

41. WFP, IOM. Populations at risk: Implications of COVID-19 for hunger, migration and displacement. World Food Programme (WFP) and the International Organization for Migration (IOM). Accessed 11/26/2020, https://docs.wfp.org/api/documents/WFP-0000120687/download/

42. UNICEF. Protecting children from violence in the time of COVID-19. UNICEF. Accessed 11/26/2020, $\quad$ https://data.unicef.org/resources/protecting-children-from-violence-in-the-time-ofcovid-19-brochure/

43. Lee J. Mental health effects of school closures during COVID-19. Lancet Child Adolesc Health. 06 2020;4(6):421. doi:10.1016/S2352-4642(20)30109-7

44. Townsend E. Debate: The impact of school closures and lockdown on mental health in young people. Child Adolesc Ment Health. 11 2020;25(4):265-266. doi:10.1111/camh.12428

45. Gunnell D, Appleby L, Arensman E, et al. Suicide risk and prevention during the COVID19 pandemic. Lancet Psychiatry. 06 2020;7(6):468-471. doi:10.1016/S2215-0366(20)30171-1 
46. John A, Okolie C, Eyles E, et al. The impact of the COVID-19 pandemic on self-harm and suicidal behaviour: a living systematic review [version 1; peer review: 1 approved]. F1000Research. 2020;9doi:10.12688/f1000research.25522.1

47. Orben A, Tomova L, Blakemore SJ. The effects of social deprivation on adolescent development and mental health. Lancet Child Adolesc Health. 08 2020;4(8):634-640. doi:10.1016/S2352-4642(20)30186-3

48. UNICEF. Education on hold. A generation of children in Latin America and the Caribbean are missing out on schooling because of COVID-19. UNICEF. Accessed 11/18/2020, https://www.unicef.org/lac/en/reports/education-on-hold

49. Freedberg L. Sal Khan says distance learning can't fully replace in-person instruction. Edsource. https://edsource.org/2020/sal-khan-says-distance-learning-cant-fully-replace-in-personinstruction/637541

50. Keeping schools open needs to be prioritized. https://schools.forhealth.org/risk-reduction$\underline{\text { strategies-for-reopening-schools/ }}$

51. UNICEF. Averting a lost COVID generation. A six-point plan to respond, recover and reimagine a post-pandemic world for every child. Accessed 11/24/2020, https://www.unicef.org/reports/averting-lost-generation-covid19-world-childrens-day-2020-brief

52. UN. Convention on the Rights of the Child. UN Human Rights. Accessed 11/24/2020, https://www.ohchr.org/en/professionalinterest/pages/crc.aspx 


\section{Figure Legends}

Figure 1: School reopening timelines by country and general mortality heat map over the same period.

On the left, a Gantt chart for each country grouped by regions that shows the status of the country's schools' functional status between January and November 2020. In green, the schools that have their doors fully open (Category 0: no measures taken, or category 1: governments recommend on closing or all schools were open but with some alterations). In yellow those with a partial opening (Category 2: governments require closing at some levels or by categories like age, financing or partial attendance schemes). In red the schools are closed (Category 3: government require closing all levels) Source: Data from the Oxford COVID-19 Government Response Tracker (https://www.bsg.ox.ac.uk/research/research-projects/coronavirus-government-response-tracker).

On the right, a heat map of the general mortality behavior of each country by month, based on the report of new deaths per million inhabitants. Source: Coronavirus (COVID-19) Cases - Statistics and Research. (https://ourworldindata.org/covid-cases). 


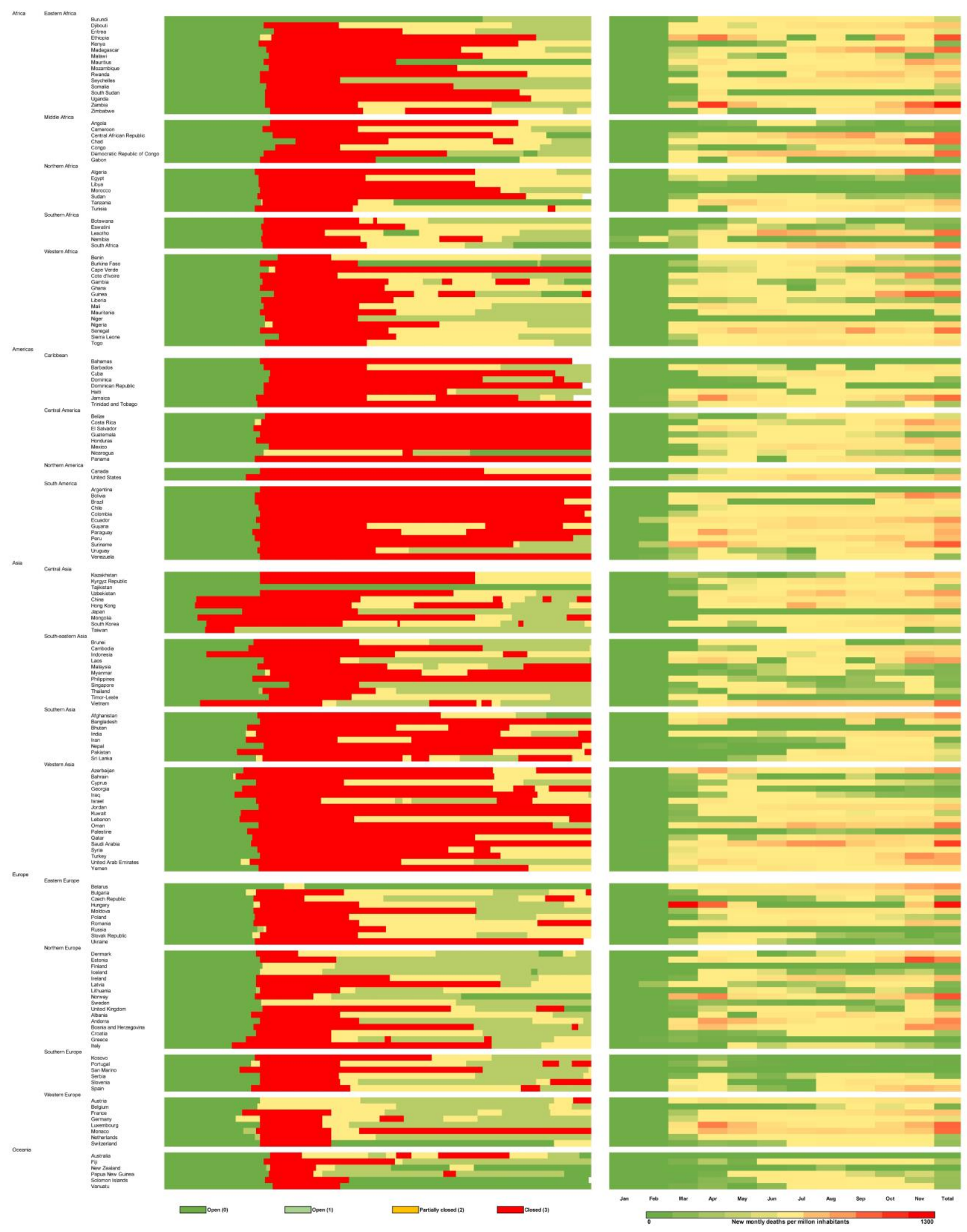


Figure 2: Global map of predominant status regarding school opening/closure during COVID-19 pandemic.

This global map describes the prevailing situation in each country in relation to the school's status (opening or closure) as of November 2020. In red, countries that have remained mainly closed (Category 3: governments require closing all levels) are described; the intensity of the color indicates whether this closure represents 0 to 337 days of the timeframe. In yellow, countries that have been mainly partially opened (Category 2: governments require closing at some levels or by categories like age, financing or partial attendance schemes). In green the countries that where fully open (Category 0: no measures taken, or category 1: governments recommend on closing or all schools were open but with some alterations). Source: Data from the Oxford COVID-19 Government Response Tracker (https://www.bsg.ox.ac.uk/research/research-projects/coronavirusgovernment-response-tracker).

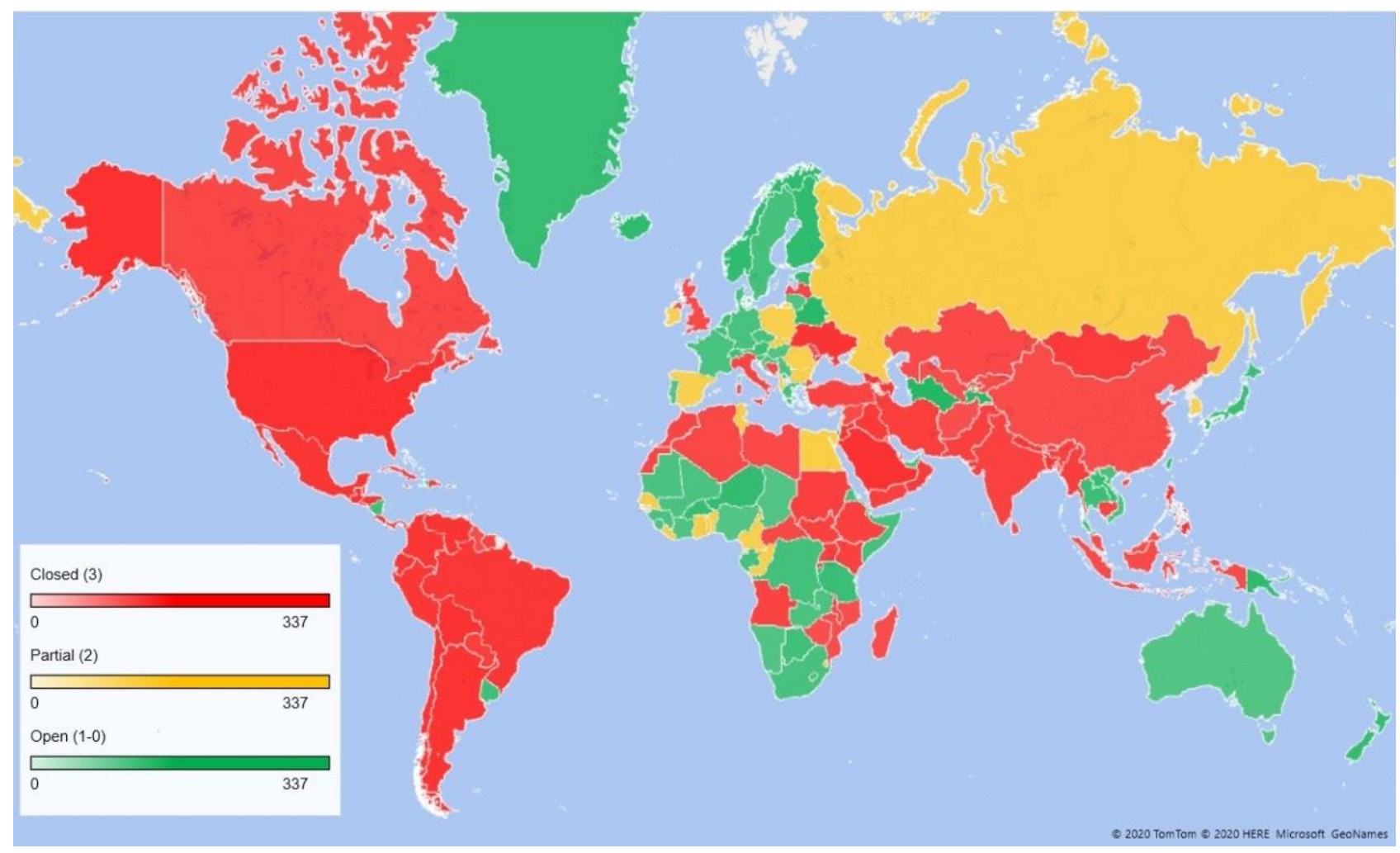


Supplementary Figure 1: School reopening timelines by country and general mortality heat map over the same period, according to interviews of professionals living within the country.

Representation of School Closures according to data collected with interviews of local colleagues. Although the supplementary figure 1 is slightly different from figure 1 , they both highlight a wide variability across different countries, independently from the COVID-19 local burden.

* The USA data regard the following cities: New York, Chicago, Philadelphia, Washington, Plesant Hill, San Francisco and Los Angeles.

* The Australian data regard the following cities: Sydney and Melbourne. 


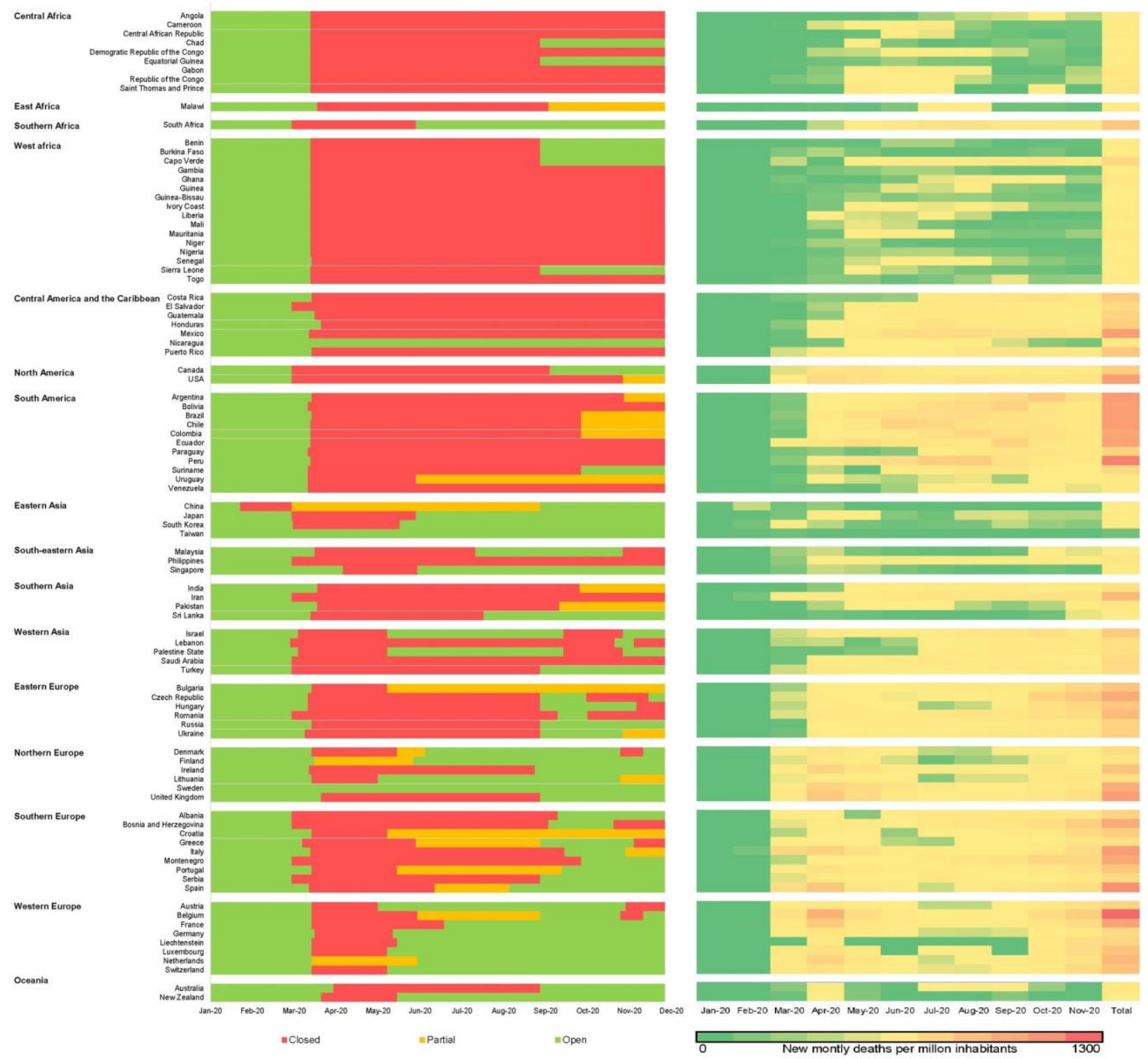




\section{Supplementary Figure 2: Global map of predominant status regarding school opening/closure} during COVID-19 pandemic, according to interviews of professionals living within the country.

This global map describes the prevailing situation in each country in relation to the school's status (opening or closure) as of November 2020, according to data collected with interviews of local colleagues.

Although the supplementary figure 2 is slightly different from figure 2 , they both highlight a wide variability across different countries, independently from the COVID-19 local burden.

* The USA data regard the following cities: New York, Chicago, Philadelphia, Washington, Plesant Hill, San Francisco and Los Angeles.

* The Australian data regard the following cities: Sydney and Melbourne.

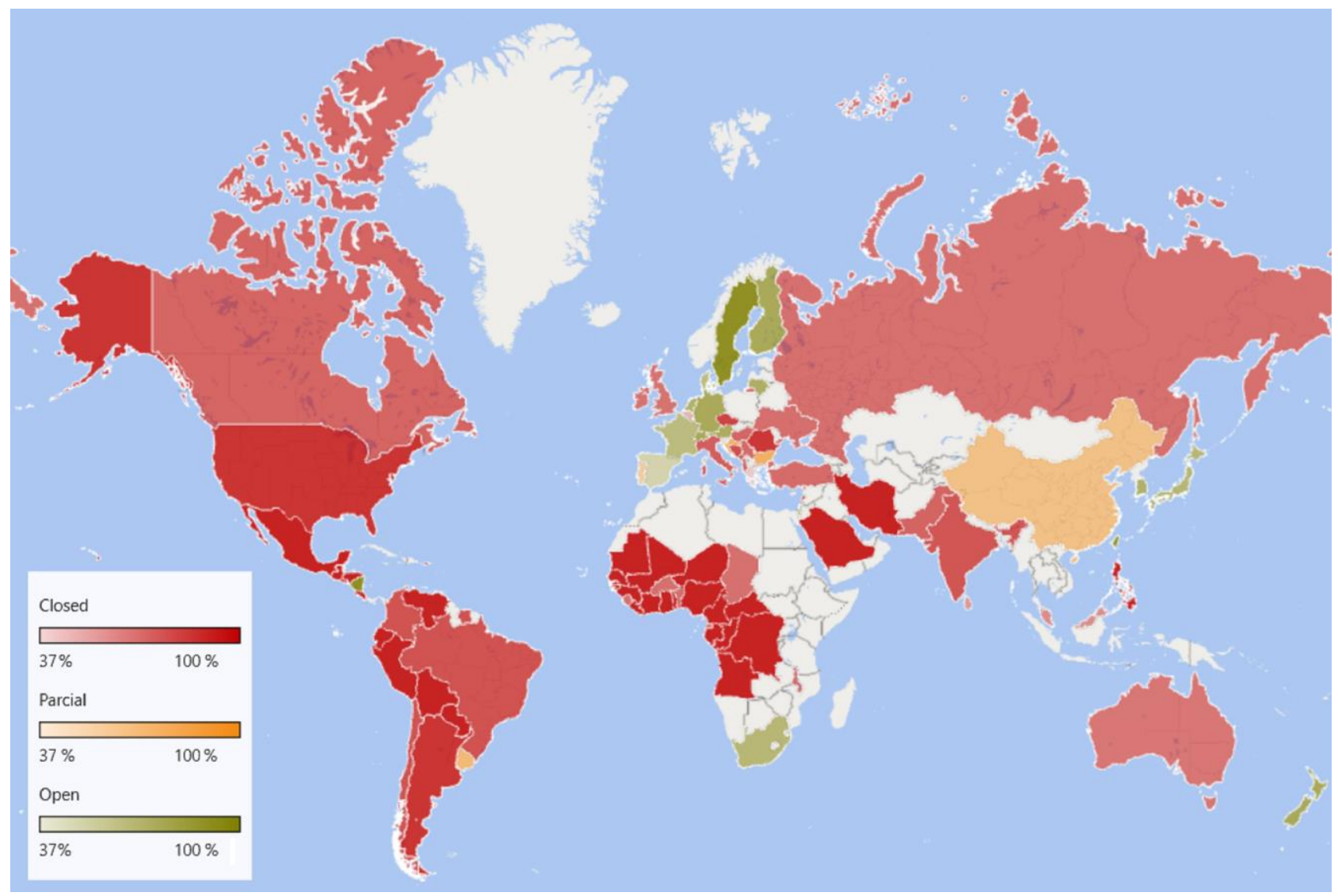

